\title{
Women Empowerment at Grassrootlevel: A Study on Women Panchayat Presidents in Tamil Nadu
}

\author{
Dr. A. Seenivasan. \\ M.A.,M.Phil.,M.Ed.,Ph.D., Asst Prof. of History. \\ A.V.C. College (Autonomous) Mannapandal - 609 305. Mayiladuthurai.
}

\section{Introduction}

Ever Since the enactment of the $73^{\text {rd }}$ and $74^{\text {th }}$ Amendments to the Constitution of India "Empowerment of women at the grassroots' has become a popular concept that is used by many with varied meanings and explanations. One third of the seats out the three levels of the grassroots institutions have been reserved for women of all categories. This has raised expectations among the different sections of the community that this group of women will become a critical mass, which in turn, will make an indelible difference to the management of these institutions at the grassroots level. Such an expectation has grown to the extent that the existing development paradigm will undergo drastic changes in the system of benefits. The traditionally bound social system the male-centric society and other institutions do mount pressures on these women at work.

\section{Social Pressures}

While looking at the issues of the women leaders, one has to bear in mind the environment in which the institutions have been created through 33.3 percent reservation of seats for women and how they have carried out the duties and responsibilities assigned to them. Right from 1941 report of the subcommittee of the National Planning Committee to the recent report of the committee and status of women in India every report has emphasized that the condition of women is unacceptable and that they have been denied their rights and opportunities. It is true that Indian history provides ample proof the rights and freedoms enjoyed by women change in inverse proportion to the status of their families, especially the men in their families with in the social hierarchy.

\section{Institutional Pressures}

Increasing of workload, illiteracy, usual shyness, domination of males, negative attitude of officials illtreatment, information blockade, domination caste panchayats, lack of communication skills, lack of managerial skills, caste discrimination and lack of motivation there problems are facing the women representatives of local bodies.

Women have come to positions in the local bodies as provision has been made in the constitution. The attitude of society towards women has started changing. But, in the process of empowering women, the hurdles are continuing. They need orientation, sensitization, capacity building, and information and counseling continuously through organization. As a result more failures, rather than success stories have been projected in the media. However, such representations are largely based on assumptions, not facts. As per government statistics failures comprise no more than 5 percent of the cases.

\section{Rural Development Programmes And Women's Empowerment In Tamil Nadu}

There are 297.8 million Women, amounting to 73.2 percent of women in India, live in rural areas and 27 percent of these rural women are below the poverty line.

These women who are living below poverty line form a part of the poor following under the same category. According to a report, 130 million people in India will be living under below poverty line even in 2012 (The Hindu, June 2004). Since this is the condition, the poor rural women who are living under the poverty line will have to suffer for a long, period, in spite of all the developing programmes the are being implemented by the state and the central governments. In short, it is a bad omen for the future of the poor rural women. Experience in rural areas shows that unless conscious efforts are made to provide adequate opportunities - the very potential female human capital would be carried out. Much had been written of evils like 'female infanticide', the socio-economic cause for the women unfavorable

Sex ratio and 'violence against women from womb to tomb'. These problems are no doubt applicable to women universally i.e. in rural and urban areas, but they are compounded in rural areas due to greater intensity of poverty, ignorance and women's disempowerment on several counts.

Rural development involves 'maximizing benefits from developmental assets' and minimizing the adverse impact of developmental liabilities'. To facilitate this, given their large numbers and vulnerability, 
special attention needs to be shown for the development of rural women and their integration in the development process.

Poor women are in greatest need to supplement their family income. Studies like those of D.R.Gadgil in his, 'Women in the Working Force in India' show that the maximum number of working days in agricultural labour for women in rural areas in 180 days in the wet zone, and 85 days in the dry zone. This shows that despite economic necessity and the willingness to work, women are unemployed for a great part of the year. The daily wages that women earn in agriculture are also very merely at a mere estimated average of Rs.10.65 paisa per day.

Poor women, especially those steeped in life cycle poverty or long term dependency poverty, are not in a position to go on their own during the large spells of unemployment as they lack adequate economic resources. The numerous difficulties they face include inadequate skills, limited control and access to the mans and factors of production (Viz. land, credit, lab our, technology and marketing), illiteracy, inhibiting societal norms and lack of supportive services to lighten their burden.

There is a significant gap especially among poor women in agricultural labour, between their potential and actual productivity. The extent of their underemployment has been highlighted in studies which show that surplus lab our can be drawn out in significant numbers without affecting productivity.

The Indian society is not favourable to women and it treats her as a person of weaker sex, born to play a subordinate role in the society. This is the status of the Indian women in general but, the condition of the rural women is still worst. Poverty provides the opportunity to the rich to ill-treat them the social and economic forces keep them weak, marginalized and in the position of a "Second class citizen".

The thoughtful and sympathetic social workers, social scientists, and others who had the opportunity to study the condition of the rural women, came to realize the urgent need for eradicating poverty and inequality from their lives. The government of India also to realize the same need, and the result was the Development of Women and Children in rural Areas (DWCRA) Programme and other women upliftment programmes. The Indian Government, when began to pan for the development of nation, had clearly understood that the upliftment of women was an equally important factor for the nation's development.

\section{Role Of Khadi And Village Industries Commission In The Rural Developments In Tamil Nadu.}

The Ministry of Commerce and Industry was introduced a bill known as Khadi and Village Industry Commission bill in the Parliament of India in April 1955. in 1956, the bill was passed and the Khadi Board was converted into the Khadi and Village Industries Commission.

In Tamil Nadu the Khadu and Villagem Industries Board was constituted by an Act passed in the State Legislative Assembly in 1959 and the state Tamil Nadu Khadi and Village Industries Board aims at providing employment in the rural areas to the unemployed and the under employed and in augmenting and improving their daily incomes. It introduces improved tools and techniques for the benefits of the village workers. Schemes are implemented through the State's Departmental Units, Co-operative Societies and through motivated individuals. Funds are received from All India Khadi and Village Industries Commission and also from the state government for the various plan and non-plan schemes.

In order to have a closer relationship with the various implementing agencies in Tamil Nadu, the Khadi and Village Industries Commission's state level office was started in the year 1959 at Trichur and it was shifted to Maders during the year 1962.

As the Tamil Nadu Khadi and Village Industries Board was a statutory body set up under and Act of the State Legislation, its Annual Report and Audited Accounts were placed on the table of the state Legislature regularly. This gave an opportunity to the representative of the people to discuss the various programmes and offer their suggestions for improving the implementations of the programmes.

Among the various implementing agencies in Tamil Nadu, the Registered Institutions had played an important role in the development of the Khadi and Village Industries through various action programmes. Even prior to the formation of the Tamil Nadu Sarvodaya Sangh and the Tamil Nadu Khadi and Village Industries Board, a number of important major institutions like the Gandhi Ashram at Tirchengodfu, Gandhiniketan Ashram, at T.Kallupatti, Gandhigram Rural Institute at Dinidingul and the like, were engaged in the promotion of the Khadi and Village Industries in Tamil Nadu. These have been registered under the Societies Registration Act of 1860. At present there are large number Registered Institutions including the Sarvodaya Sanghs in Tamil Nadu. All these institution are motivated bodies for carrying out developmental activities in the rural areas. Among the Registered Institutions the Tamil Nadu Sarvodaya Sangu Units occupy a unique and predominant position. 


\section{Village Industries Co-operative Societies:}

Industries Co-Operative societies are organized for the development of village industries. These societies are formed and registered under the Tamil Nadu co-operative societies Act. The Chief Executive Officer is the functional registrar of the Co-operative societies. Officers of the Board have been given powers under the Act for efficient governance of the societies. There were 1823 industries Co-operative societies functioning under the control of the board in 1992-93. Sixteen Industrial Co-operative societies have been formed mostly for hand-pounding of paddy, pottery, brick and tile making, palmgur, leather tanning and son on. The Tamil Nadu Khadi the Village Industries Board has successes in register more number of co-operative Units for the development of the village industries compared to that of the other states. Khadi and Village Industries have a vital role to play in the diversification of industries in the rural economy of the India and there by help to achieve an integrated rural development. An evaluation of KVI institutions would give a valuable feed back for planning for further development of the activities of these institutions in the pursuit of the objectives of an integrated rural development of the people but also the development of peace, love, cooperation and integration in their day to day life.

\section{Conclusion}

India's experiments with local self government go back to ancient times Ancient and medieval inscriptions attest to the marvelous arrangements of local self government. In some form or other this tradition continued even during the British period. The viceroyalty of Lord Rippon had given a new thrust to decentralization in local administration. But the decentralization as conceived by the British had governed more powers to those villagers who would become the loyal supporters of the British. Things began to change after India's independence. Democracy through general elections, emergence of regional political awakening in the country side.

So long as the congress hegemony was there up to 1967, the local administration was organized haphazardly in Tamil Nadu. After 1967 the local governments came to be dominated by non-congress parties. It is to be noted that the entry of parties in the village politics coincided with the Dravidian politics and its propaganda against the congress. But when the date was announced of election all the political parties view with one another to nominate party candidates for the election. Previously the President of the village Panchayat was elected indirectly by ward members.

\section{Secondary Sources: Books.}

[1] Abdul Aziz, Decentralisation-Mandal Panchayat System in Karnataka, Hydrabad, 1995

[2] Abraham Mathew, Role of panchayats in Welfare Administration, Kalpooz Pubilcations-Delhi-2005.

[3] Amareswar Mishra, Urban Government and Administration in India, Meerut, 1986.

[4] Amreshwar Avasthi.S. Public Administration, Agra, 2002. Amitava Mudherjee, New Panchayat Raj institusious in New Delhi, 2004.

[5] Anju Bhatia, Women's Development and NGO's- New issues in Panchayati, Calcutta, 1982

[6] Arulselvam.M. Tamil Nadu Urban Localbodies rules, Chennai, 2000.

[7] Ashok Kumar Jha, Women in Panchayat Raj Institutions, New Delhi, 2004. Barthwal.C.p. Understanding Local Self-Government. Lucknow, 1977.

[8] Bhagwant Singh,Panchayat Raj in India, Tomar, 1991.

[9] Bhupinder Singh, Role of Democratic Decentralisation, New Delhi, 1999.

[10] Chopra,J.K. Local Self-Government and Municial Administration, New Delhi,1990.

[11] Dipen Roy, Finance and Accounting of Panchayat Raj Institutions in West Bengal, Delhi, 2005.

[12] Eric Jackson, Local self Government in England And Wales, London, 1951.

[13] Gaikward.V.R.Rural Development Administration Under Democratic Decentralization,New Delhi, 1983.

[14] Gagan Kukmar Singh, Administration for RuralDevelopment Programmes in India, Delhi,2003.

[15] Gokulanda Dash,Municipal Finance in India,New Delhi,1988.

[16] Guru Samy, M.P.(Ed.,) Nirmana Thittankal Ikkala Thevai (Tamil) Dindigul.2002.

[17] Hasnat Abdul Hye, integrated Rural Development in Bangladesh, Bangalore, 1990.

[18] Hemingway.F.R.Trichinopoly Gazetteer, Madras, 1907. 